\title{
PROTEIN-BOUND IODINE LEVELS IN MOTHERS AND INFANTS AT BIRTH
}

BY

\author{
I. KESSEL and W. M. POLITZER
}

From the Department of Paediatrics, University of the Witwatersrand, and the Queen Victoria Maternity Hospital, Johannesburg, South Africa, and the South African Institute for Medical Research

(RECEIVED FOR PUBLICATION MARCH 25, 1957)

The protein-bound iodine level in the blood is important in relation to thyroid gland activity.

Various aspects of blood iodine are discussed by Samson Wright (1952). Iodine is present in the blood in the hormone form of thyroxine and diiodotyrosine bound with albumin and precipitated out with the serum proteins, the proteinbound or precipitable iodine; the normal range of this hormone iodine is 3.5 to $8 \mu \mathrm{g}$. per $100 \mathrm{ml}$.

Kennedy and Hayles (1948) mention that proteinbound iodine levels may be raised to values of 10 to $12 \mu \mathrm{g}$. per $100 \mathrm{ml}$. during pregnancy and in early infancy.

Iodine is also found in the blood as inorganic iodide or filterable iodine, the level of which is dependent on iodine intake; this is not related to thyroid gland activity as is the protein-bound iodine. In patients with hypothyroidism the protein-bound iodine levels are reduced; in hyperthyroidism the level is raised.

The present report represents a study to determine normal levels of protein-bound iodine in the serum of mothers taken within an hour of the delivery of an infant and the levels in the serum of umbilical cord blood of their infants taken immediately after delivery. The protein-bound iodine was determined by the method of Connor, Swenson, Park, Gangloff, Lieberman and Curtis (1949) as modified by Van Zyl (1953). Table 1 presents the

TABLe 1

OBSTETRIC HISTORIES OF THE SERIES

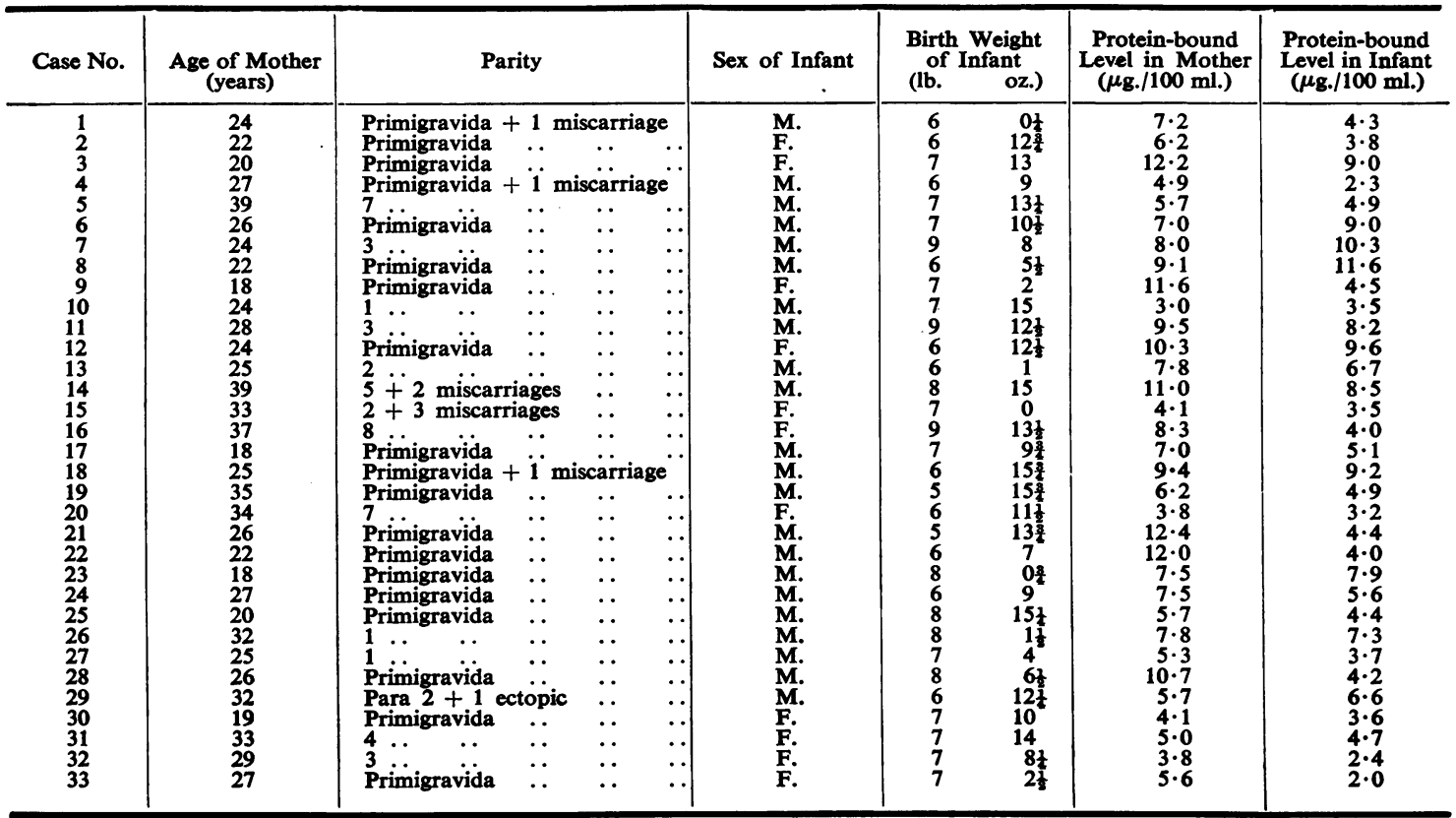


details of the age and parity of the mothers and the sex and birth weights of the infants.

\section{Discussion}

Thirty-three cases were included in this study. In six cases the protein-bound iodine level was higher in the infant's cord blood than in the mother's blood; these cases were all males. The proteinbound iodine levels in the mother's blood ranged from 3.0 to $12.4 \mu \mathrm{g}$. per $100 \mathrm{ml}$. and in the infant's cord blood from 2.0 to $11.6 \mu \mathrm{g}$. In 21 of the mothers and also in 21 infants the protein-bound iodine level range was between $3 \cdot 5$ and $8 \mu \mathrm{g}$. per $100 \mathrm{ml}$. and in only one mother and four infants was the level below $3.5 \mu \mathrm{g}$. per $100 \mathrm{ml}$. In 11 mothers and eight infants the level was over $8 \cdot 0 \mu \mathrm{g}$. per $100 \mathrm{ml}$.

\section{Summary}

Protein-bound iodine levels in the blood of mothers and their newborn infants were studied with a view to establishing a normal pattern.

We wish to thank the Director of the Institute for his interest, Prof. C. S. Heyns, Dr. L. G. R. van Dongen and Dr. F. Daubenton for allowing us the facilities at the Queen Victoria Maternity Hospital, the labour ward staff for their kind cooperation and Mrs. J. K. Purchase for her technical assistance.

\section{REFERENCES}

Connor, A. C., Swenson, R. E., Park, C. W., Gangloff, E. C., Lieberman, R. and Curtis, G. M. (1949).' Surgery, 25, 510 Kennedy, R. L. J. and Hayles, A. B. (1948). Brennemann's Practice of Pediatrics, vol. 1 , Chapter 38, p. 6. Hagerstown, Maryland. Van Zyl, A. (1953). S. Afr. J. med. Sci., 18, 61 .

Wright, Samson (1952). Applied Physiology, 9th ed., p. 976. London. 